\title{
Methionine, Lysine and Choline in Dairy Cows: a Review Article
}

\author{
Khwairakpam Ratika ${ }^{*}$, R.K. James Singh ${ }^{2}$ and S.S. Dahiya ${ }^{3}$ \\ ${ }^{1}$ Division of Animal Nutrition, ICAR-National Dairy Research Institute, \\ Karnal-132001, India \\ ${ }^{2}$ Division of Veterinary Biotechnology, ICAR-Indian Veterinary Research Institute, Izatnagar, \\ Bareilly-243122, India \\ ${ }^{3}$ Division of Animal Nutrition and Feed Technology, ICAR-Central Institute of Research on \\ Buffaloes, Hisar-125001, India \\ *Corresponding author
}

\begin{tabular}{|l|l}
\hline \multicolumn{1}{l|}{} & \multicolumn{1}{c}{ A B S T R A C T } \\
\cline { 2 - 3 } \multicolumn{1}{l|}{$\begin{array}{l}\text { Key words } \\
\text { Methionine, Lysine, } \\
\text { Choline, Dairy } \\
\text { cows }\end{array}$} & $\begin{array}{l}\text { Provision of nutrients in balanced form and required amount is crucial to meet the } \\
\text { productive targets in dairy cows. Among the various nutrients, protein is the most } \\
\text { important nutrient for milk production. Methionine and lysine are considered as the first } \\
\text { and second limiting amino acids for milk protein synthesis because of their low } \\
\text { concentrations in feed protein as compared to their concentrations in milk and ruminally } \\
\text { synthesized bacterial protein. Choline, a component of phospholipid and methyl donor, } \\
\text { plays an essential role in biosynthesis and secretion of milk. In addition, choline is a } \\
\text { component of the neurotransmitter acetylcholine and is used to synthesize the ubiquitous } \\
\text { phospholipid, phosphatidylcholine, via the cytidinediphosphate choline pathway. As } \\
\text { dietary methionine, lysine and choline are degraded extensively in the rumen, additional } \\
\text { methionine, lysine and choline are supplemented in rumen protected form. About 28\% of } \\
\text { absorbed methionine is used for choline synthesis. Supply of methionine and choline } \\
\text { enhance the capacity of liver to export triacylglycerol (TAG) in the form of VLDL and } \\
\text { help ameliorate the negative effects of fatty acid accumulation in the liver soon after } \\
\text { parturition. }\end{array}$ \\
\hline $\begin{array}{l}\text { Accepted: } \\
\text { Available Online: } \\
\text { 10 July 2018 }\end{array}$
\end{tabular}

\section{Introduction}

India is the highest milk producing country in the world. The population of buffaloes in India is over 108 million, which is approximately $57 \%$ of total world buffalo population (BAHS, 2012) contributing 50 million tons of milk, which accounts for $55 \%$ of total milk production (92 million tons) in India (FAO, 2011). High producing animals requirement for dietary essential amino acids are higher from those supplied by the microbial protein. High intakes of crude protein (CP) in the diet, and/or improved supply and ratios of amino acids should be delivered to the duodenum in order to meet animal needs for milk and milk protein synthesis. If, such amino acids are not supplied through diet and /or microbial protein from the rumen, the animal production in terms of growth and milk production are 
bound to reduce. Increasing the dietary protein intake is not a satisfactory solution because this will breakdown in the rumen and microbial protein alone cannot supply all the nutrition of a productive animal. To overcome this, dietary protein sources that are considered to be good sources of "bypass" or rumen undegradable protein have been used. (Dahiya et al., 1991; Chaturvedi and Wali, 1993). Dietary supplementation of rumen protected protein and amino acids are recommended to support the physiological and productive needs of livestock for amino acids. Thus, protecting the amino acids from ruminal degradation has made it possible to supplement diets with specific amino acids that will become available directly for absorption in intestine (NRC, 2001).

For milk production, methionine and lysine are considered to be first and second limiting amino acids. Methionine is related to production of milk fat because of its role as a methyl donor in transmethylation reactions in lipid biosynthesis (Lehninger, 1977). This deficiency is understandable for Lys, because of its high metabolic requirement for milk protein synthesis (King et al., 1991), particularly in diets in which corn protein with high undegradable intake protein (UIP) and low Lys constitutes a significant proportion of dietary CP. NRC (2001) suggested that concentrations of Lys and Met in metabolizable protein (MP) for maximal use of MP for milk protein production are 7.2 and $2.4 \%$, respectively. As rumen microbial protein synthesis cannot supply sufficient quantities of amino acids to meet the requirements of cows producing large quantities of milk (Polan et al., 1991, Ali et al., 2009), dietary supplementation of Met and Lys in rumen protected form can therefore be an effective approach to improve amino acid balance for milk production.

Choline is a key compound for the synthesis of two important molecules, phosphatidylcholine (PC) and acetylcholine (Pinotti et al., 2002). Phosphatidylcholine is essential to maintain cell membrane structure (Davidson et al., 2008), hepatic synthesis and secretion of very low density lipoprotein (VLDL) from the liver (Cooke et al., 2007), and biosynthesis and secretion of milk (Kinsella, 1969); whereas acetylcholine is an important neurotransmitter (Pinotti et al., 2002). High producing dairy cows secrete 3 to $5 \mathrm{~g} / \mathrm{d}$ of choline in milk, whereas duodenal supply is usually less than that. Low availability of dietary choline, extensive secretion of choline through milk and limited precursor from the tetrahydrofolate pathway, especially at the onset of lactation suggested that choline may be a limiting nutrient for milk production. In ruminants, dietary choline is rapidly and extensively degraded in the rumen from studies with both sheep (Neill et al., 1979) and cattle (Atkins et al., 1988; Sharma and Erdman, 1988).

\section{Animal biology during the transition period}

Transition cows are those which transit from dry pregnant state to lactating non pregnant state and this period lasts from 3 weeks before parturition to 3 weeks after parturition (Goff and Horst, 1997). This period is characterized by dramatic physiological and metabolic adaptations, and the animal is at the highest risk of succumbing to health disorder during this period (Loor et al., 2013). During 20 days before calving, the dry matter intake declines as compared to normal, owing to stress. To cater to the energy requirement for the development of the fetus, the animal starts mobilizing fat two weeks prior to calving and there is increase in non esterified fatty acid (NEFA). The increase in the amount of NEFA reaching the liver results in a significant increase in liver activity beyond the capacity of liver to completely oxidised NEFA which ultimately lead to fat accumulation. Fat accumulation in the liver may also give rise to a variety of health issues such as fatty liver 
and ketosis. The liver plays an important role in converting ammonia to urea. Accumulation of fat in the liver reduces the ability of the liver to detoxify ammonia into urea (Strang et al., 1998).

\section{Task of methionine, lysine and choline in transition buffaloes}

Dietary energy intake does not meet nutrient demand of rapid foetal growth and postnatal lactation which results in a negative energy balance (Roche et al., 2013). In order to meet the increasing energy demands, there is fat mobilization which subsequently elevates nonesterified fatty acids level in the bloodstream (Karimian et al., 2015). NEFA can be metabolized in liver in three ways: (1) complete oxidation to generate ATP in hepatic mitochondria or peroxisomes, (2) incomplete oxidation to produce ketone bodies, including acetone, acetoacetate, and $\beta$-hydroxybutyric acid (BHBA), or (3) re-esterification to form triglycerides (TG). The TG can either accumulate in hepatocytes or be transported out of the liver in the form of very-low-density lipoprotein (VLDL). However, the ability to completely oxidize NEFA and synthesize VLDL is limited, thereby increasing the incidence rates of ketosis and fatty liver (Grummer et al., 2004). Choline and methionine help in the transport of hepatic lipids by promoting the synthesis of phosphatidylcholine to package VLDL. Specifically, both of them play vital roles in 1carbon units transfer of dairy cows, modulate the synthesis of S-adenosylmethionine (SAM) in methionine cycle, and SAM functions as the most important methyl donor in the phosphatidylethanolamine to phosphatidylcholine formation (Osorio et al., 2014). Fat metabolism can be improved with the help of choline for better energy production. This also helps in improving milk production that the use of NEFA for ATP is sensitive to carnitine supply (Drackley et al.,
1991). Carnitine is a quasi-vitamin required for the transport of NEFA into mitochondria where fatty acids undergo $\beta$-oxidation process. Choline acts as a methyl donor and helps in the synthesis of carnitine through various biochemical processes. Therefore, choline indirectly may act to reduce the accumulation of fat on liver by providing carnitine to enhance hepatic fatty acid oxidation.

\section{Milk yield and composition}

The potential of milk production of dairy cows can be exploited through fulfilling nutritional requirements in terms of protein and energy. Two essential amino acids lysine (Lys) and methionine (Met) are limiting amino acids for optimum milk production in early lactation of these animals and are derived from dietary source and are usually supplemented in the rumen protected form. Recently, Zanton et al., (2014) performed a meta-analysis on 64 studies that examined effects of feeding rumen-protected methionine. The most consistent effect they have observed was increased protein percent and yield but milk fat percent and yield were found increased in some studies only. While no significant effect of methionine supplementation on milk yield was noticed. Supplemental ruminally protected methionine did not increase milk production but did increase milk protein percentages in cows fed barley-based diets (Casper and Schingoethe, 1988).

Supplementation of lysine in diet containing double-low rapeseed meal of lactating cows increased milk yield, 4\% FCM and concluding that rumen protected lysine is beneficial for improving lactational performance of cows (Liu et al., 2016).

Similarly, Pas et al., (2014) suggested that feeding supplemental rumen-protected Lys to Holstein Friesian cows producing more than $36 \mathrm{~kg} / \mathrm{d}$ can result in improved concentrations 
of fat and protein and yield of ECM, but cows producing less than $36 \mathrm{~kg} / \mathrm{d}$ do not respond positively.

Amrutkar et al., (2014) supplemented $5 \mathrm{~g}$ rumen protected methionine (RPM) and $20 \mathrm{~g}$ rumen protected lysine (RPL), prepartum and $7 \mathrm{~g} \mathrm{RPM}$ and $60 \mathrm{~g}$ RPL, postpartum to control diet i.e. chopped wheat straw, chaffed green maize fodder and concentrate mixture in periparturient dairy cows and observed that milk yield in supplemented group was 17.36 $\mathrm{kg} / \mathrm{d}$, which was $14.21 \%$ higher $(\mathrm{P}<0.05)$ than that of control group $(15.20 \mathrm{~kg} / \mathrm{d})$. Milk fat, protein and lactose yield per day was also higher $(\mathrm{P}<0.05)$ by $17.39,14.86$ and $13.91 \%$ in supplemented group than that of control group, respectively. On the other hand, Awawdeh (2016) reported no effect of rumen protected methionine and lysine on milk yield and milk composition except milk protein in Holstein dairy cows. Zhou et al., (2017) investigated whether methionine and lysine have additional effect or not on milk yield and milk composition of dairy cows and they came to the end that RPM plus RPL improved milk yield and protein contents of dairy cows and was better than supplying RPM alone. Ahmed et al., (2015) also found the same effect of rumen protected lysine and methionine on the production performance of early lactating Nili-Ravi buffaloes and suggested that for the optimum production performance in early lactating Nili Ravi buffalos, lysine and methionine supplementation can be a part of their ration.

Bonomi et al., (1996) compared rumen protected choline (RPC) in the diet of Italian Fresian dairy cows at three doses (2, 6 and 10 $\mathrm{g}$ choline chloride/d) and unprotected choline $(2,6,10 \mathrm{~g} / \mathrm{d})$, found that RPC at three doses $(2,6$ and $10 \mathrm{~g} / \mathrm{d}$ ) and $10 \mathrm{~g} / \mathrm{d}$ of unprotected choline significantly improved milk production $(6.75,8.8, \quad 10$ and $5 \%$ respectively), milk fat $(4,4.3,6$ and $3.1 \%$ respectively) and milk protein content (4.7, 5.6, 7.5 and $3.5 \%$ respectively). On the other hand, used of unprotected choline at the dose of $2 \mathrm{~g} / \mathrm{d}$ and $6 \mathrm{~g} / \mathrm{d}$ was found to be uneffective.

Pawar et al., (2015) conducted evaluated the effect of supplementing rumen protected choline (RPC) on milk yield, composition and milk choline content of crossbred cows and they came to the results that choline supplementation had no effect on milk yield and composition, however, milk choline content was higher $(\mathrm{P}<0.05)$ in $\mathrm{RPC}$ supplemented groups. And suggested the lowest dose of $54 \mathrm{~g}$ RPC/cow/d best for feeding to animals because beyond that level there was no additional benefit in terms of increase in milk choline content in crossbred cows. In another study, Mohsen et al., (2011) noticed that rumen-protected choline supplementation in lactating Friesian cows led to increased actual milk yield by 1.32 and 2.24 $\mathrm{kg} / \mathrm{head} /$ day or 8.75 and $14.85 \%$, and $4 \%$ fat corrected milk (FCM) by 1.55 and 2.60 $\mathrm{kg} / \mathrm{head} /$ day or 10.86 and $18.31 \%$ for 15 and $30 \mathrm{~g}$ RPC compared with un-supplemented RPC, respectively $(\mathrm{P}<0.05)$. The contents of fat and total solids (TS) and the yield of all milk constituents except ash increased significantly $\quad(\mathrm{P}<0.05) \quad$ with $\quad \mathrm{RPC}$ supplementation. Rumen protected choline supplementation in dairy cows had no effect on milk yield but had greater milk protein, milk solids and milk fats as compared to non supplemented group (leiva et al., 2015). Whereas, Suksombat et al., (2012) informed that milk composition did not alter in milk of Holstein cows when RPC was added in the diet.

Garg et al., (2012) studied the effect of choline supplementation along with bypass fat on milk yield in Jaffarabadi buffaloes $(n=27)$ where group 1 buffaloes were fed control diet; buffaloes in group 2 were supplemented daily with $150 \mathrm{~g}$ bypass fat per animal and in group 
3 along with $150 \mathrm{~g}$ bypass fat, $15 \mathrm{~g}$ rumen protected choline chloride was also fed and they observed that average increase in milk yield and fat of groups 2 and 3 were $1.26 \mathrm{~kg}$ $(\mathrm{p}<0.05)$ and $0.31 \%(\mathrm{p}<0.05)$ and $1.55 \mathrm{~kg}$ $(\mathrm{p}<0.01)$ and $0.44 \%(\mathrm{p}<0.05)$, as compared to group 1.

Supplementation of rumen protected methionine- lysine and rumen protected choline to lactating cows increased milk yield, 4\% FCM due to improved digestibility of nutrients (Sheikh et al., 2014; Amrutkar et al., 2015)

\section{Somatic cell count}

Supplementation of methionine in lactating dairy cows had no significant effect on somatic cell count (SCC) of milk (Izumi et al., 2000). Contrary, Li et al., (2016) found reduced somatic cell count in milk of Holstein Friesian cows fed diet supplemented with methionine (Smartamine M). Pirestani et al., (2011) reported reduction in somatic cell count of milk due to choline supplementation in Holstein Freisian cows. On the other hand, Park et al., (2008) observed that rumen protected choline did not affect somatic cell count.

\section{Feed intake}

Feed intake and body weight gain response to supplemental rumen protected methionine, lysine and choline had been variable. In formulating diets, it is not only important to satisfy requirements for rumen degradable protein and rumen undegradable protein, also to ensure a balanced ratio between the first limiting amino acids, methionine and lysine, as well as with other amino acids. Moreover, balancing amino acids gives the opportunities to formulate diets that improve the cow's health and reproductive performance and decrease nitrogen excretion (Liu et al., 2013).
Broderick et al., (2008) conducted a trial on 36 Holstein cows supplemented with either 0 or $8 \mathrm{~g}$ of rumen protected methionine (RPM) per animal per day and found no significant difference in dry matter intake between the treatments. Ordway et al., (2009) checked whether different forms of rumen protected methionine (MetaSmart and Smartamine) supplementation had different effect on dry matter intake in Holstein Freisan cows. Animals were supplemented from 21 days before expected calving and continued through 140 days postpartum. The results indicated that prepartum DM intake (DMI; $13.5 \mathrm{~kg} / \mathrm{d})$, body weight $(687 \mathrm{~kg})$, body condition score (3.81), were not different among treatments. However, postpartum DMI and body condition score were greater for cows fed the MetaSmart diet than for cows fed the control and Smartamine $M$ diets. In another study, Soltan et al., (2012) investigated the effect of supplementing rumen protected methionine ( $15 \mathrm{~g} /$ day) and / or choline $(30 \mathrm{~g} / \mathrm{day})$ on performance of sixty lactating Holsteins dairy cows. RP- MET improved DMI by $.07 \%$ when compared with MET limited group, while RP- CHOL significantly improved DMI by $8.4 \%$ throughout the whole experimental period when compared with the control group cows. On the other hand, there was improvement only in postpartum dry matter intake (DMI) in transition cows fed diet supplemented with rumen protected methionine and choline (Sun et al., 2016).

Donkin et al., (1989) observed the effect of RPM and RPL in eight mid lactation Holstein cows by addition of protected-methionine (15 $\mathrm{g} /$ day) and lysine (40 g/day) and found no significant differences between treatments on dry matter intake. Armentano and Swain (1993); Chung (2003) also achieved the same results when methionine and lysine was supplemented in Holstein Friesian. Also, there was no significant effect on DMI when only 
rumen protected lysine was supplemented in Holstein Friesan cows (Pas et al., 2014).

No significant effect on prepartum DMI (Lima et al., 2007) and postpartum DMI (Leiva et al., 2015) in transition dairy cows due to rumen protected choline. Also, Elek et al., (2008) and Guretzky et al., (2006) also reported choline supplementation in Holstein Friesian cows had no effect on BCS and dry matter intake. Suksombat et al., (2012) and Rahmani et al., (2014) also reported no effect on dry matter intake, body weight, due to choline supplementation in Holstein Friesian. Sheikh et al., (2014) supplemented rumen protected methionine plus lysine and choline in Karan Fries fed basal ration consisting of wheat straw (20\%), green fodder $(40 \%)$ and concentrate mixture (40\%) as per NRC (2001). Eighteen Karan Fries were divided into three treatments as follows: T1 group were supplemented with $7 \mathrm{~g}$ rumen protected methionine plus $60 \mathrm{~g}$ rumen protected lysine per day and those in $\mathrm{T} 2$ group were given $60 \mathrm{~g}$ rumen protected choline per day. DMI was higher $(\mathrm{P}<0.05)$ in $\mathrm{T} 1$ and $\mathrm{T} 2$ groups than that of control (C) and the digestibility of OM, $\mathrm{NDF}$ and ADF was higher in in $\mathrm{T} 1$ and $\mathrm{T} 2$ than that of control.

\section{Haemato- biochemical parameters}

High milk producing dairy animals may undergo negative energy balance which triggers body fat mobilization to meet the increasing energy demands of the animals. As a result of fat mobilization, higher levels of non-esterified fatty acids (NEFA) are generated in adipose tissue and released into the blood circulation. Higher NEFA concentration is a typical hallmark of transition cows, and the insufficient metabolic capability of hepatic NEFA has been demonstrated to adversely affect animal health and to impair lactation performance as well as subsequent reproductive performance (Ospina et al., 2010). NEFA circulating in blood can be either utilized by the mammary gland to synthesize milk fat or transported to the liver for further metabolism (Grummer et al., 2004). Choline and methionine serve as crucial nutrients for assembly of VLDL to export TG from liver.

Gao et al., (2008) supplemented rumen protected methionine (RPMet) in the diet of Chinese Holstein cows and found out that $6 \mathrm{~g}$ RPMet supplementation in the diet of lactating cows significantly decreased serum urea nitrogen $(P<0.01)$ and glucose contents $(P<$ $0.05)$, but had no effects on nonesterified fatty acids (NEFA), total cholesterol and triglyceride $(P>0.05)$. Rumen protected methionine induced no significant effect on blood serum glucose, triglycerides, NEFA and blood urea concentration while reduced $(p<0.05)$ blood serum cholesterol when compared with methionine limited group (Soltan et al., 2012).

Krober et al., (2000) studied the effect of adding lysine and/or methionine in 24 Brown Swiss cows. They obtained the results that the effects of lysine and methionine on various enzyme activities (glutamyl transferase, aspartate amino transferase and creatine kinase) and plasma metabolites such as glucose, triglycerides, NEFA did not differ significantly. But, in another study, it was reported that cows on pelletized concentrate containing Lys and Met with or without choline tended to have lower serum nonesterified fatty acid, but no differences were observed in other blood parameters (Ye et al., 2010). Concentrations of blood metabolites, except for betahydroxybutyrate (BHB), were not changed due to addition of rumen protected methionine and lysine in dairy cows (Tricnaty et al., 2009).

RPC supplementation tended to improve blood metabolic profile in transition dairy 
cows and the optimal dose of feeding of RPC is $30 \mathrm{~g} / \mathrm{d} \quad(\mathrm{Xu}$ et al.,2006) Dietary incorporation of rumen protected choline in dairy cows increased plasma concentrations of glucose whereas nonesterified fatty acids (NEFA), triglycerides and cholesterol were decreased (Xu et al., 2006; Mohsen et al., 2011). Soltan et al., (2012) also found the same results in Holstein dairy cows except increased cholesterol concentration. Garg et al., (2012) also supplemented $15 \mathrm{~g}$ of rumen protected choline in Jaffarabadi buffaloes where they found reduced NEFA and cholesterol level as compared to nonsupplemented groups. In contrast, Suksombat et al., (2012) reported that rumen protected choline supplementation in Holstein cows had no effect on blood parameters. Guretzky et al., (2006) incorporated $60 \mathrm{~g}$ of a RPC product (25\% choline as choline chloride) from $21 \mathrm{~d}$ before expected parturition through $21 \mathrm{~d}$ postpartum Holstein cows and realized that cows fed Rumen protected choline tended to have greater serum triglycerides prepartum $(17.0$ vs. $14.7 \mathrm{mg} / \mathrm{dL})$ and lower plasma phospholipid at parturition (65.2 vs. 78.1 $\mathrm{mg} / \mathrm{dL}$ ) than control cows but treatment did not affect cholesterol and phospholipid at other time points.

Amrutkar et al., (2015) conducted an experiment on crossbred (Karan-Fries) cows of between $2^{\text {nd }}$ and $4^{\text {th }}$ lactation. Animals in the Control group (T1) were offered with a basal diet consisting of threshed wheat straw, chopped green maize forage and compounded concentrate mixture as per their requirements. Animals in second group (T2) were fed with $5 \mathrm{~g}$ of rumen-protected methionine and $20 \mathrm{~g}$ of rumen- protected lysine and in third group (T3), $54 \mathrm{~g}$ of rumen-protected choline was supplemented in addition to basal diet 40 days before and 120 days after calving. Results revealed that plasma metabolites like glucose, non-esterified fatty acids, cholesterol and plasma urea nitrogen were similar among all groups. Concentration of triglycerides and very low density lipoproteins was lower $(P<0.01)$ in T2 and T3 than Control group. However, phosphatidylcholine and vitamin $\mathrm{E}$ levels were higher $(P<0.01)$ in T3 than other two groups. It was concluded from the study that supplementation of rpMetLys and rpCholine to high-yielding crossbred cows improved metabolic health status during early lactation period under Indian situation.

\section{Immunity}

There is decreased dry matter intake (DMI) in cows around the calving period so the ingested nutrients could not support the dietary requirements for milk production. Cows during this period experienced marked negative energy balance (NEB) and depressed immune function. The decreased immune function during the peripartum period is partly responsible for metabolic diseases and infections (Sordillo et al., 2009). Many researchers have demonstrated that methionine, besides being first limiting amino acids for milk production, also plays role in immune function (Soder et al., 1999 and Osorio et al., 2013). Methionine and its derivate metabolites like glutathione, taurine, polyamines are popular immunonutrients in non-ruminants that aid and boost immune function and activity. Both methionine and choline were found to increase immune function effectively; but, methionine affected the immune and antioxidant status before parturition, which might have been beneficial to prepare the cow to respond to metabolic challenges after parturition (Vilaiti-Riboni et al., 2017). Choline and methionine have been shown to alleviate oxidative stress as well as enhance immunity in rodents and humans (Miller et al., 2005; Luo and Levine, 2009).

Excessive production of reactive oxygen species (ROS) from normal metabolism leads to loss of cell function, necrosis and apoptosis 
and decreases dairy cow performance (Miller et al., 1998). Hu et al., (2005) reported that inhibition of SOD2 caused accumulation of ROS. Li et al., (2016) observed greater expressions of SOD1 and SOD2 in methionine supplemented group as compared to non supplemented group of dairy cows.

Sun et al., (2016) investigated the effects of rumen-protected methionine (RPM) and rumen-protected choline (RPC) on antioxidant capacity and immune response in transition dairy cows and showed that post-ruminal choline and methionine elevated the blood antioxidant status, as indicated by total antioxidant capacity (T-AOC), glutathione peroxidase (GSH-Px) activity and the vitamin E concentration $(P<0.05)$, and reduced the plasma malondialdehyde (MDA) level $(P<$ 0.05). Also, RPM and RPC elevated the plasma interleukin 2 (IL-2) concentrations and the $\mathrm{CD}^{+} / \mathrm{CD}^{+} \mathrm{T}$ lymphocyte ratio in peripheral blood $(P<0.05)$. And the levels of tumor necrosis factor- $\alpha$ (TNF- $\alpha$ ) and IL-6 were found to be decreased by RPM and RPC $(P<0.05)$ supplementation. The results demonstrated that dietary supplementation with RPC and RPM enhanced antioxidant capacity and immune function of transition dairy cows. Osorio et al., (2013) proposed that blood neutrophil phagocytosis at $21 \mathrm{~d}$ was greater with methionine supplementation, suggesting better immune function.

\section{Diseases and reproduction}

During transition period, there is excessive fat mobilization to support milk and milk fat synthesis and higher level of NEFA in blood is noted. But due to limited ability of liver to completely oxidised NEFA to ATP or packed into VLDL, there is incomplete oxidation of NEFA to form ketone bodies, making dairy cows are more susceptible to metabolic diseases like ketosis, fatty liver, retained placenta, hypocalcemia and clinical mastitis
(Esposito et al., 2014). This metabolic diseases compromise reproductive performance of dairy cows. Feeding rumen protected choline reduced the incidence of clinical ketosis, mastitis, and morbidity, and the number of cases of mastitis per cow. Feeding RPC did not influence cyclicity and pregnancies per AI (Lima et al., 2011). First service conception rate was increased by feeding rumen-protected choline in two studies (Oelrichs et al., 2004; Lima et al., 2007). Supplementation of RPM and RPC have been improved reproductive performance and health situation of dairy cows (Ardalan et al., 2009). A study (Ikeda et al., 2012) evaluated whether methionine metabolism was required for normal development of bovine embryos and methionine was found to have an essential role in the development of the bovine embryo from morula to blastocyst.

Cows fed choline exhibited decreased ketone body concentration numerically in urine (2.22 \pm 1.40 vs. $2.62 \pm 1.66$ in control; $\mathrm{P}=0.34)$ which suggests a sign for reduced incidence for ketosis (Ensink et al., 2013).

\section{Stress conditions}

The heat and humidity of a typical summer make a very uncomfortable environment for lactating dairy cows. During hot summer weather, milk production may decrease and reproductive proficiency of lactating dairy cows is greatly diminished. Abdi-Benemar et al., (2015) evaluated the effects of balancing low protein diets for methionine and lysine on performance of early lactation Holstein cows under hot environmental temperature. Twenty one multiparous Holstein cows in early lactation were allocated to three experimental rations including, 1) High protein ration with $17.5 \% \mathrm{CP}, 2)$ Medium protein ration with $16 \% \mathrm{CP}$ and $12 \mathrm{~g} / \mathrm{d}$ rumen protected methionine (RP Met), 3) Low protein ration with $14.5 \% \mathrm{CP}, 14 \mathrm{~g} / \mathrm{d} \mathrm{RP}$ Met and $5 \mathrm{~g} / \mathrm{d}$ 
rumen protected lysine. There was no effect of ration on milk yield and milk fat percentage, but milk protein percent, $\mathrm{N}$ efficiency for milk production, milk urea nitrogen (MUN) and blood urea nitrogen (BUN) were affected significantly. $\mathrm{N}$ excreted in urine, $\mathrm{N}$ balance and creatinine concentration in urine decreased significantly by feeding low protein diets. Plasma concentrations of non-essential AA were not affected by treatments but, Methionine, Valine and Leucine concentrations were affected significantly. They suggested that low protein diets with rumen protected amino acids can be an alternative for high protein diets for dairy cows under hot climates.

In conclusions, for optimum milk production, methionine, lysine and choline are required in the diet in the rumen protected form in high producing dairy cows. Supplementing these nutrients during the transition period can be profitable for commercial dairy farming. Methionine and choline have shown to enhance immune status of animals and alleviate stress to liver thereby decreasing the occurrence of metabolic diseases.

\section{References}

Abdi-Benemam, H., Rezayazdi, K., DehghanBanadaky, M. and Kachuee, R. 2015. Effect of balancing low protein diets for methionine and lysine on performance of early lactation Holstein cows in hot environmental temperature. Journal of Livestock Science and Technologies. 3 (1): 24-33.

Ahmed, S., Gohar, M., Khalique, A., Ahmad, N., Shahzad, F., Burhan-e-Azam, Rahman, A. and Khan, M. I. 2016. Effect of Supplementation of Rumen Protected Lysine and Methionine on Production Performance, Milk and Blood Parameters of Early Lactating Nili-Ravi Buffaloes. Pakistan Journal of Zoology. 48(2): 359-363.

Ali, C. S., Sharif, M., Nisa, M., Javaid, A., Hashmi, N. and Sarwar, M. 2009. Supplementation of Ruminally Protected Proteins and Amino Acids: Feed Consumption, Digestion and Performance of Cattle and Sheep. Int. J. Agr. Biol. 11: 477-482.

Amrutkar, S. A., Pawar, S. P., Thakur, S. S., Kewalramani, N. J. and Mahesh, M. S. 2015. Dietary Supplementation of Rumen-Protected Methionine, Lysine and Choline Improves Lactation Performance and Blood Metabolic Profile of Karan-Fries Cows. Agricultural Research. 4(4): 396-404.

Amrutkar, S. A., Thakur, S. S. and Pawar, S. P. 2014. Influence of Rumen Protected Methionine and Lysine Supplementation on Milk Production, Composition and Nutrient Utilization in Periparturient Dairy Cows. Indian J. Ani. Nutr. 31(2): 110-118.

Ardalan, M., Rezayazdi, K. and DehghanBenadaky, M. 2009. Investigation on the effect of supplementing rumen protected forms of methionine and choline on health situation and reproductive performance of Holstein dairy cows. Pakistan journal of biological sciences. 12(1):69-73.

Armentano, L.E. and Swain, S.M. 1993. Lactation response to ruminally protected methionine and lysine at two amounts of ruminally available nitrogen. Journal of Dairy Science. 76: 2963-2969.

Atkins, K. B., Erdman, R.A. and Vandersall, I. H.1988. Dietary choline effects on milk and duodenal choline flow in dairy cattle. J. Dairy Sci. 71:109-112.

Awawdeh, M. S. 2016. Rumen-protected methionine and lysine: effects on milk production and plasma amino acids of dairy cows with reference to metabolisable protein status. Journal of 
Dairy Research. 83(2): 151-155.

BAHS (Basic Animal Husbandry and Fisheries Statistics). 2012. Department of Animal Husbandry, Dairying \& Fisheries. GOI, New Delhi.

Bonomi, A., Quarantelli, A., Bonomi, B.M., Sabbioni, B. and Superchi, P. 1996. Inclusion of rumen protected choline in diets for dairy cattle: effect on productive and deficiency. Journal of Food Science Nutrition.25: 413-434.

Broderick, G.A., Stevenson, M. J., Patton, R. A., Lobos, N. E. and Colmenero, J. J. 2008. Effect of supplementing rumenprotected methionine on production and nitrogen excretion in lactating dairy cows. J. Dairy Sci. 91:1092-1102.

Casper, D. P. and Schingoethe, D. J. 1988. Protected Methionine Supplementation to a Barley-Based Diet for Cows During Early Lactation. Journal of Dairy Science. 71(1): 164-172.

Chaturvedi, O. H. and Walli, T. K.1993. In Proceedings of $\mathrm{Vi}$ Animal Nutrition Research Workers', Conference, Bhubaneswar.

Chung, Y. H. 2003. Effects of free methionine and lysine on in vitro fermentation and in vivo performance and ruminal fermentation of late lactation Holstein cows. Master's thesis. B. S., Chinese Culture University, Taiwan.

Cooke, R.F., Silva Del Rio, N., Caraviello, D. J., Bertics, S. J., Ramos, M. H. and Grummer, R. R. 2007. Supplemental choline for prevention and alleviation of fatty liver in dairy cattle. J. Dairy Sci. 90: 2413-2418.

Dahiya, S. S., Sengar, S. S. and Mudgal, V. D. 1991. Effect of feeding urea (ammonia) treated wheat straw with cotton seed cake on nutrient utilization and milk production in buffaloes. Int. $J$. Anim. Sci. 6: 133-137.

Davidson, S., Hopkins, B. A., Odle, J., Brownie, C., Fellner, V. and Whitlow,
L. W. 2008. Supplementing limited methionine diets with rumen-protected methionine, betaine, and choline in early lactation Holstein cows. J. Dairy Sci. 91: 1552-1559.

Donkin, S. S., Varga, G.A., Sweeney, T.F. and Muller, L.D. 1989. Rumenprotected methionine and lysine: effects on animal performance, milk protein yield and physiological measures. $J$. Dairy Sci. 72: 1484-1491.

Drackley, J. K., Veenhuizen, J. J., Richard, M. J. and Young, J. W.1991. Metabolic changes in blood and liver of dairy cows during either feed restriction or administration of 1,3 butanediol. $J$. Dairy. Sci. 74(12): 4254-64.

Elek, P., Newbold, J.R., Gall, T., Wagner, L. and Husventh, F. 2008. Effects of rumen protected choline supplementation on milk production and choline supply of peri-parturient dairy cows. Anim. 2(11):1595-1601.

Ensink, J., Kampf, D. and Orffa, A. B.V.2013. Effects of rumen protected choline chloride in dairy cows. Proc. 51. Jahrestagung der Bayrischen Arbeitsgemeinschaft Tierernährung e.V., Freising (Germany), pp.77-80.

Esposito, G., Irons, P.C., Webb, E. C. and Chapwanya, A. 2014. Interactions between negative energy balance, metabolic diseases, uterine health and immune response in transition dairy cows. Anim Reprod Sci. 144(3-4): 6071.

FAO, 2011. Food and Agriculture Organization of the United Nations. http://faostat.fao.org.

Gao, A., Li, J., Jia, W., Li, Q. and Cao, Y. 2008. Response of lactating cows to supplemental rumen protected methionine and Niacin. Frontiers of Agriculture in China. 2(1): 121-124.

Garg, M. R., Sherasia, P. L. and Bhanderi, B. M. 2012. Effect of supplementing 
bypass fat with and without rumen protected choline chloride on milk yield and serum lipid profile in jaffarabadi buffaloes. Buffalo Bulletin. 31(2): 9198.

Goff, J. P. and Horst, R. L. 1997. Physiological changes at parturition and their relationship to metabolic disorders. J. Dairy. Sc. 80(7):1260-8.

Grummer, R. R., Mashek, D. G. and Hayirli. 2004. Dry matter intake and energy balance in transition period. Vet. Clin $N$ Am. Food Anim. 20: 447-470.

Guretzky, N. A. J., Carlson, D. B., Garrett, J. E. and Drackley, J. K. 2006. Lipid Metabolite Profiles and Milk Production for Holstein and Jersey Cows Fed Rumen-Protected Choline during the Periparturient Period. J. Dairy Sci. 89: 188-200.

Hu, Y., Rosen, D. G., Zhou, Y., Feng, L., Yang, G., Liu, J. and Huang, P. 2005. Mitochondrial manganese- superoxide dismutase expression in ovarian cancer: role in cell proliferation and response to oxidative stress. J Biol Chem. 280(47): 39485-92.

Ikeda, S., Sugimoto, M. and Kume, S. 2012. Importance of Methionine Metabolism in Morula-to- blastocyst Transition in Bovine Preimplantation Embryos. $J$ Reprod Dev. 58:91-97.

Izumi, K., Kikuchi, C. and Okamoto, M. 2000. Effect of rumen protected methionine on lactational performance of dairy cows. Asian australasian journal of Animal Science. 13(9): 123538.

Karimian, M., Khorvash, M., Forouzmand, M.A., Alikhani, M., Rahmani, H. R. and Ghaffari, M. H. 2015. Effect of prepartal and postpartal dietary fat level on performance and plasma concentration of metabolites in transition dairy cows. J Dairy Sci. 98: 330-337.
King, K. J., Bergen, W. G., Sniffen, C. J., Grant, A. L., Grieve, D. B., King, V. L and Ames, N. K. 1991. An assessment of absorbable lysine requirements in lactating cows. J. Dairy Sci. 74: 2530.

Kinsella, J. E. 1969. Biosynthesis of CholineContaining Lipids by Ruminant Mammary Tissue. 52(11): 1875-1877.

Krober, T.F., Kreuzer, M., Senn, M., Langhans, W. and Sutter, F. 2000. Lactational and metabolic effects in cows of lysine and methionine added to a ration deficient according to the I.N.R.A. method. Arch. Anim. Nutr., 53: 375-394.

Lehninger, A. L. 1977. Biochemistry. 2nd ed. Worth Publ., Inc. New York, NY.

Leiva, T, Cooke, R.F., Brandao, A.P, Marques, R.S., Vasconcelos, J.L. 2015. Effect of rumen-protected choline supplementation on metabolic and performance responses of transition dairy cows. J. Dairy Sci. 93(4):18961904.

Li, C., Batistel, F., Osorio, J. S., Drackley, J. K., Luchini, D. and Loor, J. J. 2016. Peripartal rumen-protected methionine supplementation to higher energy diets elicits positive effects on blood neutrophil gene networks, performance and liver lipid content in dairy cows. Journal of Animal Science and Biotechnology. 7:18.

Lima, F.S., Sa Filho, M. F., Creco, L. F. and Santos, J. E. P. 2011. Effects of feeding rumen-protected choline on incidence of diseases and reproduction in dairy cows. Vet J. 193(1):140-145.

Lima, F.S., Sa Filho, M. F., Greco, L. F., Susca, F., Magalhaes, V. J., Garrett, J. and Santos, J. P. E. 2007. Effects of feeding rumen-protected choline (RPC) on lactation and metabolism. J. Dairy Sci. 90(1):174.

Liu, Y. G., Peng, H. H. and Schwab, C. G. 2013. Enhancing the productivity of 
dairy cows using amino acids. Animal Production Science 53(11) 1156-1159.

Liu, G., Ma, Z., Shan, A., Wang, L. and Bi, Z. 2016. Effects of dietary rumen protected lysine on milk yield and composition in lactating cows fed diets containing doble- low rapeseed meal. International Journal of Dairy Technology. 69(3):380-385.

Loor, J. J., Bionaz, M. and Drackley.2013. Systems physiology in dairy cattle: Nutritional genomics and beyond. Annual Review of Animal Biosciences. 1:365-392.

Luo, S. and Levine, R. L.2009. Methionine in proteins defends against oxidative stress. 2009. FASEB J. 23(2): 464-72.

Miller, J. K., Campbell, M.H., Motjope, L., Cunningham, P. F. and Madsen, F.C. 1998. Antioxidant nutrients and reproductionin Dairy Cattle. $B A S F$ Nutrition News. Publication NN 9708. BASF corporation, Mount Olive, NJ.15pp.

Miller, R. A., Buehner, G., Chang, Y., Harper, J. M., Sigler, R. and SmithWheelock, M. 2005. Methionone deficient diet extends mouse lifespan, slows immune and lens aging, alters glucose, T4, IGH-I and insulinlevels and stress resistance. Aging cell. 4(3): 119-25.

Mohsen, M. K., Gaffar, H. M. A., Khalafalla, M. M., Shitta, A. A. and Yousif, A. M. 2011. Effect of Rumen Protected Choline Supplementation on Digestibility, Rumen Activity and Milk Yield in Lactating Friesian Cows. $J$. Anim. Sci. 44: 2011.

National Research Council (NRC). 2001. Nutrient requirements of dairy cattle (7th ed.) Washington, DC: National Academy of Science.

Neill, A. R., Grime, D. W., Snoswell, A. M., Northrop, A. J., Lindsay, D. B. and Dawson, R. M. C. 1979. Biochem. J.
$180,559-565$.

Oelrichs, W.A., Lucy, M. C., Kerley, M. S. and Spain, J. N. 2004. Feeding soybeans and rumen-protected choline to dairy cows during the periparturient period and early lactation. Effects on production and energy balance. J. Dairy Sci. 87 (1): 344.

Ordway, R. S., Boucher, S. E., Whitehouse, N. L., Schwab, C. G. And Sloan, B. K. 2009. Effects of providing two forms of supplemental methionine to periparturient Holstein dairy cows on feed intake and lactational performance. J. Dairy Sci. 92(10): 5154- 5166.

Osorio, J. S., Ji, P., Drackley, J. K., Luchini , D. and Loor, J. J. 2014. Smartamine M and MetaSmart supplementation during the peripartal period alter hepatic expression of gene networks in 1-carbon metabolism, inflammation, oxidative stress, and the growth hormone-insulinlike growth factor 1 axis pathways. $J$. Dairy Sci. 97:1-14.

Osorio, J. S., Ji, P., Drackley, J.K., Luchini, D. and Loor, J.J. 2013. Supplemental Smartamine M or MetaSmart during the transition period benefits postpartal cow performance and blood neutrophil function. J. Dairy Sci. 96:6248-63.

Ospina, P. A., Nydam, D. V., Stokol, T. and Overton, T. R. 2010.Associations of elevated nonesterified fatty acids and $\beta$ hydroxybutyrate concentrations with early lactation reproductive performance and milk production in transition dairy cattle in the northeastern United States. J Dairy Sci. 93: 15961603.

Park, B. K., Kim, B. W., Jang, H. Y. and Shin, J. S. 2008. Effects of Rumen Protected Choline on In vitro Ruminal Fermentation and Milk Production and Its Composition in Lactating Cows. Journal of the Korean Society of Grassland and Forage Science. 28(3): 
255-264.

Pas, J. K. B., Chandler, P. T., Sniffen, C.J. and Chaulapa, W. 2014. Response of cows to rumen protected lysine after peak yield. The Professional Animal Scientist. 30(4): 407-412.

Pawar, S. P., Kewalramani, N., Thakur, S. S. and Kaur, J. 2015. Effect of Dietary Rumen Protected Choline Supplementation on Milk Choline Content in Crossbred Cows. Indian Journal of Animal Nutrition. 32 (1): 3035.

Pirestani, A., Aghakhani, M. Tabatabaei, S, N., Ghalamkari, G. and Baharlo, F. 2011. Effects of dietary L-Carnitine and Choline Chloride Compound on Reproduction Indices and Udder Immune System in Holstein Dairy Cattle. International Conference on Life Science and Technology. 3: 59-61.

Pinotti, L., Baldi, A. and Dell'Orto, V. 2002. Comparative mammalian choline metabolism with emphasis on the highyielding dairy cow. Nutr. Res. Reviews. 15: 315-331.

Polan, C. E., Cummins, K. A, Sniffen, C. J, Muscato, T. V, Vicini, J. L., Crooker, B. A., Clark, J. H., Johnson, D. G., Otterby, D. E, Guillaume, B., Muller, L. D., Varga, G. A, Murray, R. A. and Peirce-Sandner, S. B. 1991. Response of Dairy Cows to Supplemental RumenProtected Forms of Methionine and Lysine. J Dairy Sci. 74: 2997-3013.

Rahmani, M., Dehghan- Banadaky, M. and Kamalyan, R. 2014. Effects of Feeding Rumen Protected Choline and Vitamin E on Milk Yield, Milk Composition, Dry Matter Intake, Body Condition Score and Body Weight in Early Lactating Dairy Cows. Iranian Journal of Applied Animal Science. 4(4): 693698.

Roche, J. R., Bell, A. W., Overton, T. R. and Loor, J. J. 2013. Nutritional management of the transition cow in the 21st century?-A paradigm shift in thinking. Anim Prod Sci. 53: 10001023 .

Sharma, B. K. and Erdman, R. A. 1989. In vitro degradation of choline from selected feedstuffs and choline supplements. J. Dairy Sci. 72: 27712776.

Sheikh, F. A., Kewalramani, N., Thakur, S. S. and Mir, I. A. 2014. Effect of Supplementation of Rumen Protected Methionine-lysine and Choline on Milk Production in Crossbred Cows. Indian Journal of Animal Nutrition. 31 (2): 148-151.

Soder, K. J. and Holden, L. A. 1999. Lymphocyte proliferation response of lactating dairy cows fed varying concentrations of rumen-protected methionine. J Dairy Sci. 82:1935-42.

Soltan M.A, Mujalli A.M, Mandour M.A. and Abeer M.E. 2012. Effect of dietary rumen protected methionine and/or choline supplementation of rumen fermentation characteristics and protective performance of early lactating cows. Pak J Nutr. 11(3):221230.

Sordillo, L.M., Contreras, G. A. and Aitken, S. L. 2009. Metabolic factors affecting the inflammatory response of periparturient dairy cows. Anim Health Res Rev.10:53-63.

Strang, B. D., Bertics, S. J., Grummer, R. R. and Armentano, L. E. 1998. Effect of long chain fatty acids on triglyceride accumulation, gluconeogenesis, and ureagenesis in bovine hepatocytes. $J$. Dairy. Sc. 81(3): 728-39.

Suksombat, W., Homkao, J. and Klangnork, P. 2012. Effect of biotin and rumen protected choline supplementation on milk production, milk composition, live weight change and blood parameters in lactating dairy weights. J. Anim. Vet. 
$A d v$. 10:2186-2192.

Sun, F., Cao, Y., Cai, C., Li, S., Yu, C. and Yao, J. 2016. Regulation of Nutritional Metabolism in Transition Dairy Cows: Energy Homeostasis and Health in Response to Post-Ruminal Choline and Methionine. PLOS ONE DOI:10.1371/journal.pone.0160659..

Tricnaty, J., Krizova, L., Richter, M., Cerny, V. and Riha, J. 2009. Effect of rumenprotected methionine, lysine or both on milk production and plasma amino acids of high-yielding dairy cows. Czech $J$. Anim. Sci. 54 (6): 239-248.

Valaiti-Riboni, M., Zhou, Z., Jacometo, C. B., Minuti, A., Trevisi, A., Luchini, D. N. and Loon, J.J. 2017. Supplementation with rumen-protected methionine or choline during the transition period influences whole-blood immune response in periparturient dairy cows. $J$ Dairy Sci. 100(5): 3958-3968.

Xu, G. Z., Ye, J. A., Liu, J. X., and Wu, Y. M. 2006. Effect of rumen-protected choline addition on milk performance and blood metabolic parameters in transition dairy cows. Asian- Australasian Journal of Animal Science. 19: 390-395

Ye, J, A., Wang, C., Wang, H. F., Liu, H. Y., Wang, Y. M. and Chen, B. 2010. Effects of pelletizing and supplementary methionine, lysine, and choline on the performance of periparturient dairy cows. Acta Agriculturae Scandinavica. 60(10): 230-238.

Zanton, G. I., Bowman, G.R., Vazquez-Anon, M. and Rode, L. M. 2014. Meta analysis of lactation performance in dairy cows receiving supplemental dietary methionine sources or postruminal infusion of methionine. J. Dairy Sci. 97:7085-7101.

Zhou, Z., Vailati-Riboni, M., Luchini, D, N. and Loor, J. J. 2017. Methionine and Choline Supply during the Periparturient Period Alter Plasma Amino Acid and One-Carbon Metabolism Profiles to Various Extents: Potential Role in Hepatic Metabolism and Antioxidant Status. Nutrients. 9(10): 1-19.

\section{How to cite this article:}

Khwairakpam Ratika, R.K. James Singh and Dahiya, S.S. 2018. Methionine, Lysine and Choline in Dairy Cows: a Review Article. Int.J.Curr.Microbiol.App.Sci. 7(07): 3921-3934. doi: https://doi.org/10.20546/ijcmas.2018.707.456 